\title{
Employee Turnover Intention through Human Resource Management Practices: A Review of Literature
}

\author{
H M Mahfuzur Rahman ${ }^{1 *}$ and Valliappan Raju ${ }^{2}$ \\ ${ }^{1} \mathrm{PhD}$ Aspirant, Post Graduate Centre, Limkokwing University of Creative Technology, Malaysia. ${ }^{2}$ Associate Professor, Post Graduate \\ Centre, Limkokwing University of Creative Technology, Malaysia.
}

\begin{abstract}
This paper focused on analysing the results of previous studies conducted by different researchers to examine the effect on turnover intention of HRM activities such as training and development, job security, performance appraisal and compensation. This research would also investigate the methods of human resource management as an independent variable and the intention of turnover as a dependent variable. A quantitative approach to assessing the effects of each variable has been implemented on the basis of these research objectives. The study therefore concluded that HRM activities can be applied as a method for the turnover intention of the employee.
\end{abstract}

Keywords: Human resource management practices, turnover intention.

\section{INTRODUCTION}

HRM refers to the techniques and activities associated with the completion of the management role of the human resource asset components, including the organisation of human resources, job security, recruiting, selection, orientation, compensation, performance appraisal, training and development, and labour relations (1). The management of human resources (HRM) can refer to the policies and practices involved in the execution of human resource (HR) functions, including human resource planning, job security, recruiting, selection, orientation, compensation, performance appraisal, training and development and labour relations (2). HRM can also be described as a composite of policies, procedures and systems that affect the behaviour, attitude and performance of employees. HRM actions are defined as organisational exercises organised to deal with the HR pool and to ensure that resources are used to achieve organisational objectives (3). Human resources strategies are organisational instruments that can be implemented to recruit and maintain the best qualified workers to accomplish organisational goals, according to $(4,5)$ suggested that every organisation's performance depends on its employees performance, and the effective organisations recognised that certain variables contribute to performance, but the most important is undoubtedly human resource management practice. In order to attract, maintain and add creative shareholder value, it is important to incorporate human resource management practices. Best HR practises will only guarantee the accomplishment of business organisations in current knowledge organisations where value is protected in the leaders of the workforce (6). The main objective of this analysis is to examine the effect on turnover intention of HRM practices.

*Address of Correspondence: H M Mahfuzur Rahman, PhD Aspirant, Post Graduate Centre, Limkokwing University of Creative Technology, Malaysia.

E-mail-hmmr.hrmp@gmail.com

(Received 06 November 2020; Accepted 11 November 2020) 


\section{LITERATURE REVIEW}

The aim of this study is to examine the results of previous studies conducted by different researchers to examine the HRM activities in which organisations should follow the purpose of the employee to improve their turnover. And some of them are here:

\section{A. Training and Development:}

Training is the protection of the software that helps employees to perform as per the required norm. It is an experience, a discipline or a planned activity that creates new skills and learning and predetermined behaviour for individuals (7). Training and development are a method for expanding a worker's efficiency, and their action is often corrected (8). Few studies have considered training and development as an instrument for enhancing workplace performance (9).

Training and growth are considered to be the fast forecast that affects productivity and output of employees (10). Training and growth are described as the process by which employees acquire the skills, capacity and knowledge related to the work needed by the company $(11,12)$ Suggests that training and development is an activity for the development of human resources aimed at enhancing the job performance of workers through equipping staff with an effective and productive way to complete the mission through individual and community improvement. At the same time, (13) notes that preparation demonstrates a substantial partnership with the goal of turnover. According to (14), training and development aims to strengthen the experience of workers as well as encourage their skills.

Training programmes will help to fill the skills gap between the current and necessary competencies in order to successfully achieve the organisational objectives. Efficient training programmes contribute to higher productivity, lower work turnover and greater employee satisfaction (15). Despite our desire, the connection between training and the intention to leave is not mediated by job integration. Instead, preparation is straight forwardly employee's plan to leave. In addition, an empirical study found that training is an essential feature of HR activities that, for individual and organisational changes, is considered to be a different type of human capital investment (16).

\section{B. Job Security:}

Job security has shown that work security concerns are not favorable and this is demonstrated by the weak quality of its activity over the past 10 years, as a result of heavy competition in postal services, and interviews have shown that the communications industry (17). In addition to the lack of in-service training programs in the company, the majority of workers in the sector have no necessary qualifications.

The aim of this question was to request answers to support the results provided from the respondents' records (18). The results showed that the company has job security, but it does not use it productively to support the workers, despite the fact that job security remains a symbol of better success in a work environment, largely because it motivates their workers to devote their professional attention to the job in order to achieve the organisation's goal. One of the discussants noted that as a protection for job security, it helps to ensure that the fundamental dignity that any human being is entitled to enjoy as an employee in an organisation is given to employees $(19,20)$, job security is how the worker feels about the business or about certain aspects of it. That is how his work has several individual desires (satisfaction) or aversions (dissatisfaction) (21). The articulation job satisfaction speaks to how a lot of an employee enjoys pleasures in the organisational environment. It is the impression of the union between singular individual interests with what is provided by the organisation (22). The most common causes of work satisfaction are these factors. It is important to emphasise that, in an organisational sense, the expression of job satisfaction reflects the pleasures of individual experience (23). Then, the root of these encounters reflects each of these variables.

The multidimensional vision was adopted in this study to link each feature of the construct to the purpose and strength of turnover. The two most used methods are the global unique classification and the sum of the points created by various aspects of the work; perhaps, these are the ones that seek job satisfaction from a unidimensional point of view with a more comprehensive frame of mind that does not care about its particular points of view and criticizes the multidimensionality of construction, featuring the measurements or measurements make complicated theoretical formulations and elaborations about the principle differ according to the circumstances.

The multidimensional vision was acquired in this research, expecting to connect every part of the creation to the function of turnover, just like its strength. In this study, 
Siqueira (2008) used an instrument composed of sub-scales, referring to particular aspects of the job relevant to satisfaction. As per Siqueira (2008), researching job satisfaction means assessing how much the company's offered returns in wages and promotions satisfy the worker, how much he / she is comfortable with the associates and the supervisors, and how much the employee's undertakings make him / her happy and give a feeling of joy. The future relationships between organisational obligation and turnover intention (24) will be drawn closer in the grouping.

\section{Performance Appraisal:}

Performance appraisal is a great instrument for assessing the performance level of employees with the defined norm, which is fixed and used worldwide (25). Where the degree of performance of an employee is placed and a performance evaluation is a reliable and annual or periodic mechanism and methods for surveying the importance of the job performance, job efficiency, job rotation and productivity of an individual employee on certain pre-established parameters and organisational targets where pre-established and pre-established targets are (26).

Accordingly, enhancing performance appraisal is required to measure and explain the standard of performance in keeping up with everyone should be among the most noteworthy outcomes of contemporary organizations (27). Performance evaluation has been regarded as the most important fundamental method for an organisation, since the data and outcomes it offers are deeply useful in deciding on choices with regard to different staff aspects such as promotion requirements and performance calculation and long-term and merit increases (28).

Previous research highlights the significance of performance assessment in the method of Organization. In this method, in contrast to certain set standards, the performance of workers is measured and evaluated. It also helps to evaluate workers ' skills and their commitment to the company. It is an important part of the organisation, we can claim, and brings benefits to both the individual and the organization (29).

Research by Zhang (2012) has found a strong link between performance evaluation and employee performance, but this association is negligible. The performance evaluation framework may have an effect on five core results, according to Sumlin (1998), i.e. efficiency, product quality, financial performance, work satisfaction and customer satisfaction.

Likewise, Hewitt Associates (1994) analysed the influence of performance evaluation on organisational success and found a major impact on efficiency and financial performance. They compared those companies that have a system of performance management with those that don't. It concluded that those businesses who have such system in place have higher revenues, market efficiency and stronger cash flows than those without such systems. They also found that efficiency in those firms with performance management systems was substantially higher and that, in addition, the financial performance of these firms increased after the implementation of such a system (30).

\section{Compensation:}

Employee compensation is a central component of the employment relationship that incorporates all types of benefits aimed at enabling workers to strive for higher productivity levels (31). Every employee deserves a reasonable compensation scheme that is in line with their talents, experiences and expertise. Organizational management must also take notice that compensation provides workers with tangible incentives for the services they provide, and serves as a source of appreciation and livelihood (32). According to (33), one of the key reasons for the high turnover of workers in companies is salary.

In support (34) a study conducted in Kenya's sugar industry found that wages were a major factor causing labour turnover. Obviously, in a report by Waititu (2013) on the analysis of factors affecting high school teacher turnover with a sample of 136 teachers, an empirical study by Mensah (2014) examined the impact of HRM practices on the retention of employees in the banking industry in Accra, Ghana found that when compensation is not given, In view of the aforementioned discussions on current employee compensation and turnover intentions literature, compensation was adopted in this study as the second construct in the prediction of turnover intention (35).

Another big HRM practice for improving work satisfaction among an organisation's workers is employee benefits. Compensation policies and an organisation's motivational incentive scheme can affect employee actions and be viewed as measures of employee attitude and concern in the organisation. In addition to satisfying specific employee expectations, Luthans (1998) defines compensation as helpful in meeting higher-level needs. When the next level of needs is reached, people are inspired to reach a higher level of needs. Compensation is 
thus considered to be the most critical variable for work satisfaction (36).

\section{E. Turnover Intention:}

The decision to stop working for a corporation is the mental reaction of an individual to clear organisational circumstances that fall down a spectrum of activities of organisational withdrawal from staring into space to the physical act of quitting (37). The majority of researchers agree that the intent of an employee to remain or leave an employer is the last cognitive step in the voluntary turnover process. As a consequence, most turnover models contain the turnover intention (38). Many related variables are revealed by research into the relationships between turnover intent and turnover intention factors. Age, gender, tenure, schooling, accessible work alternatives, job quality and job satisfaction (39) are the most influential variables.

Satisfied employees typically perform their tasks more efficiently and are less likely to be counterproductive. Job-related factors such as time pressure, lack of control, problems with the work schedule and discontent with pay in the service industries predict the intention of turnover (40). The employee continues to exhibit higher degrees of service orientation as the period of tenure of a service employee with an employer rises and the employee gradually establishes a near match with the employer. This generates an increasingly optimistic employee-employer relationship and a negative influence on the decision of the employee to leave. The essential role of organisational engagement in the turnover process has been verified in several empirical studies (41).

In different forms, labour turnover can be described. Turnover can be characterised as the individual movement through an organisation's membership boundary. Another description refers to the termination, by resignation or death, retrenchment, dismissal or retirement, of the contract between the employee and the organization (42). It is calculated as a percentage of the number of employees that have left a plant or industry over a given period of time over the total number of employees who have left the plant or industry during the same period of time (43).

Turnover is highly influenced by shifts in the labour market and the economy. Many available jobs, when the economy is good, create more rooms for growth opportunities and enable people to change their employers, leading to a higher turnover rate. In comparison, workers prefer to maintain employment during the recession, owing to the high degree of instability in the labour market (15). There are several possible reasons for turnover; often the reasons are connected to and can be handled by the organisation's HRM activities. These include topics such as non-aggressive pay, high pressure, working conditions, tedium, poor management, poor match between the worker and the activity, poor preparation, poor interchange, and other activities of the company. Many businesses do not have a structure in place to maintain their staff effectively (44).

Turnover can take several forms. Voluntary turnover happens when, out of their own free will, workers leave a company. It happens by resignation or retirement (38). The preference of the employee initiates it. Involuntary turnover happens when staff are fired, laid off, or forced to retire; where there is no option for the employee. When bad performers depart, functional turnover takes place, and when successful performers depart, dysfunctional turnover transpires (45).

Employee efficiency and attrition are also correlated with HRM activities (46). In addition (47) found evidence that the consequences of these activities are negatively linked to the turnover rates of organisations. Similarly (8) indicates that HRM activities contribute to greater involvement through substantial investment in the skills and knowledge of workers, the strengthened relationship between employer and employee, which leads to lower employee turnover rates. Organizations must limit their workers' turnover because, in terms of money and human capital, they put a burden on the organization (48). When an employee leaves the company due to the loss of human resources and the recruiting of new workers, the employer has to bear the expense (49). In the event of an employee quitting, the cost of an company needs to be nearly equal to more than a one-year salary and employee benefits. It is not just the loss of cash and money, but also the loss of data and knowledge for an organisation that hampers the organisation's presentation (50).

\section{METHODOLOGY}

A positivist theory, a deductive approach and a quantitative method accompanied by surveybased study design are employed in the research methodology.

\section{RESULT}

This research analysed numerous studies 
carried out on the effect of human resource management activities, such as training and development, job security, performance appraisal, compensation, employee turnover intention, and found a positive relationship between HRM practices and the intention of employee turnover. The study therefore concluded that HRM activities would increase the intended turnover of an employee.

\section{RECOMMENDATIONS}

It is evident from the literature review that activities in human resource management (HRM) such as training and development, job security, performance appraisal and compensation play an important role in increasing the purpose of the employee to sell. Organizations, therefore, should:

- Provide a range of job security to initiate conduct that facilitates high efficiency.

- Conduct performance reviews to measure the organisation's employee performance.

- Provide opportunities for professional growth and help workers retain the skills they need in the work market and stay viable.

- Provide appropriate conditions for employee engagement to maximise productivity.

- $\quad$ Offer a robust system of compensation that contributes significantly to recruiting and maintaining competitive human capital and can also influence the actions and purpose of turnover.

\section{CONFLICT OF INTEREST}

There is no conflict of interest in this present study. This research work is not a part of any other studies and it is our original work.

\section{REFERENCE}

1. Tanjil S, MAM Rahman, Asma JT, Tofail A. HRM Development Strategy of Different Approaches. International Journal of Informative \& Futuristic Research. 2017; 4(7): 6748-6762.

2. Nor AI. Enhancing employee performance through human resource management practices: a review of literature. European Journal of Human Resource Management Studies. 2018; 2(1): 87-95.

3. Rahman RU. Internship Report on the significance of strategic human resource management practiced by HR consultancy firms in Bangladesh to ensure proper organizational growth and employee satisfaction. 2018.

4. Rawashdeh A. The impact of green human resource management on organizational environmental performance in Jordanian health service organizations. Management Science Letters. 2018; 8(10): 1049-1058. 5. Sancho MPL, Martínez-Martínez D, Jorge ML, Madueño
JH. Understanding the link between socially responsible human resource management and competitive performance in SMEs. Personnel Review. 2018; 47(6): 1211-1243.

6. Mousa M, Ayoubi RM. "Inclusive/exclusive talent management, responsible leadership and organizational downsizing: A study of academics in Egyptian public business schools". Journal of Management Development. 2019; 38(2): 87-104.

7. Okechukwu W. Influence of training and development, employee performance on job satisfaction among the staff. Journal of Technology Management and Business. 2017; 4(1): 1-16.

8. Akkermans J, Tims M, Beijer S, De-Cuyper N. Should employers invest in employability? Examining employability as a mediator in the HRM-commitment relationship. Frontiers in Psychology. 2019;10:717.

9. Graban M. Lean hospitals: improving quality, patient safety, and employee engagement. Productivity Press. 2018.

10. Bakker AB, Demerouti E. Multiple levels in job demands-resources theory: Implications for employee well-being and performance. Handbook of well-being. 2018.

11. Hamilton RH, Davison HK. The search for skills: Knowledge stars and innovation in the hiring process. Business Horizons. 2018; 61(3):409-419.

12. Kahuria NN, Sheikh SA, Ngugi J, Muriuki D, Mwaniki AW. Role of benchmarking on employee performance in the public sector in Kenya: (A case of senior management course participants of Kenya School of Government Mombasa). The Strategic Journal of Business \& Change Management. 2018; 5(4): 2289-2299.

13. Qaisar Danish R, Shahid F, Bano S. Fawad Ali H, Afzal Humayon A. Supervision Support and Turnover Intension: Impact of Employee's Training in Banking Sector of Pakistan. European Online Journal of Natural and Social Sciences: Proceedings. 2019; 8(1 (s)):121.

14. Nguyen LT, Shao Y. The Impact of Training on Turnover Intention: The Role of Growth Need Strength among Vietnamese Female Employees. The South East Asian Journal of Management. 2019; 13(1).

15. Morrison GR, Ross SJ. Morrison JR, Kalman HK. Designing effective instruction. John Wiley \& Sons. 2019.

16. Hunde A. Factors Influencing Employee Turnover and Its Effect on Organizational Performance: The Case of Harar Beer Factory, Oromia Regional states. 2019.

17. Ursula Holtgrewe, Stefano Gasparri, Anna Ilsøe, Vassil Kirov, Monique Ramioul, Anita Sharma, Arianna Tassinari, Yennef Vereycken. Shaping Industrial Relations in a Digitalising Services Industry-Challenges and Opportunities for Social Partners. Service Markets Report. 2017. Pp- 1-46.

18. Basco RD. Kadeteng Marino under the Maritime Labor Convention, 2006: a study of minimum training and qualifications prior to shipboard training and the familiarity with onboard complaint procedures of Filipino Cadets. World Maritime University Dissertations. 2017; Pp-544.

19. Dannin E. Labor and Employment Law News-Jan-Dec 2004. Members-only Library. 2017.

20. Suharno Pawirosumarto, Purwanto Katijan Sarjana, Rachmad Gunawan. The effect of work environment, leadership style, and organizational culture towards job satisfaction and its implication towards employee performance in Parador Hotels and Resorts, Indonesia. International Journal of Law and Management. 2017; 59(6):1337-1358.

21. Morrison RL, Owler K. Relishing competence or avoiding the stretch assignment? Gender differences in what makes employees "love" work. New Zealand Journal of Human Resource Management. 2018; 8(1):3-24.

22. Harris R. Conversational Leadership: A Phenomenological Study of Exemplary High School 
Principals and the Behaviors They Practice in Leading Their Organizations. Dissertations. 2018;168.

23. Breaugh J, Ritz A, Alfes K. Work motivation and public service motivation: Disentangling varieties of motivation and job satisfaction. Public Management Review. 2018; 20(10):1423-1443.

24. Ramalho LCMD, Luiz de Paula S, de Oliveira LMB.. Organizational commitment, job satisfaction and their possible influences on intent to turnover. Revista de Gestão. 2018; 25(1): 84-101.

25. Nabi MN, Syduzzaman M, Munir MS. The impact of human resource management practices on job performances: A case study of Dhaka Bank Pvt. Ltd., Bangladesh. Human Resource Management Research. 2016; 6(2):45-54.

26. Lin N, Sauer KL. Commitment Profiles of Restaurant Employees: A Person-Centered Approach with Multigroup Structural Equation Modeling. Available at SSRN 3092290. 2017; Pp: $1-40$

27. NYABUTO L. Factors affecting organizational performance in the manufacturing sector: a case study of bidco Africa (Doctoral dissertation, MUA). 2017.

28. Lee GJ. Talent measurement: A holistic model and routes forward. SA Journal of Human Resource Management. 2018; 16(1):1-11.

29. Hislop D, Bosua R, Helms R. Knowledge management in organizations: A critical introduction. Oxford University Press. 2018; ISBN: 9780198724018.

30. Din Sirajud, Bibi Zainab, Karim Jahanvash, Bano A. HRM Practices Can Do the Miracles: A Case Study of Pharmaceutical Companies. Pakistan Journal of Social Sciences. 2014; 34(2): 637-652.

31. Howard LW, Turban DB, Hurley SK. Cooperating teams and competing reward strategies: Incentives for team performance and firm productivity. Journal of Behavioral and Applied Management. 2016; 3(3):1054.

32. Lam H, Khare A. The insourcing and backshoring dilemma: global economies fight for their share. IAFOR Journal of Business and Management. 2017; 2(2): 50-69.

33. Rissanen A. An investigation into voluntary employee turnover and retention factors in sport organizations. Mater Thesis. 2017.

34. Manthi KA, Kilika JM, Kimencu L. How Do Human Resource Management Practices Predict Employee Turnover Intentions: An Empirical Survey of Teacher Training Colleges in Kenya. International Journal of Business Administration. 2018; 9(4):201-213.

35. Manthi KA, Kilika JM, Kimencu L. How Do Human Resource Management Practices Predict Employee Turnover Intentions: An Empirical Survey of Teacher Training Colleges in Kenya. International Journal of Business Administration. 2018; 9(4): 201-213.

36. Qazi S, Jeet V. Impact of Prevailing HRM Practices on Job Satisfaction: A Comparative Study of Public and Private Higher Educational Institutions in India. International Journal of Business and Management. 2017; 12(1): 178-187.

37. Perkins G. Danger and death: organisational and occupational responses to the murder of police in South Africa-a case study (Doctoral dissertation, University of Cape Town). 2018.

38. Sun R, Wang W. Transformational leadership, employee turnover intention, and actual voluntary turnover in public organizations. Public Management Review. 2017; 19(8):1124-1141.

39. Lu ACC, Gursoy D. Impact of job burnout on satisfaction and turnover intention: do generational differences matter?. Journal of Hospitality \& Tourism Research. 2016; 40(2): 210-235.

40. Jackson LT, Fransman EI. Flexi work, financial wellbeing, work-life balance and their effects on subjective experiences of productivity and job satisfaction of females in an institution of higher learning. South African Journal of Economic and Management Sciences. 2018; 21(1):1-13.
41. Basithah N, Mohd H, Ghee WY. The impact of role stress on turnover Intention. http://umkeprints.umk.edu.my/4944/1/Conference\%20P aper\%207\%20ISEB\%202015.pdf.

42. Jamaluddin SZ, Taher MA, Yi NS. Contract of employment, key performance indicators and poor performance: a back door to dismissal or termination in malaysia?. IIUM Law Journal. 2019; 27(2):.549-569.

43. Blattman C, Dercon S. The impacts of industrial and entrepreneurial work on income and health: Experimental evidence from Ethiopia. American Economic Journal: Applied Economics. 2018; 10(3):1-38.

44. Naim MF, Lenka U. Development and retention of Generation Y employees: a conceptual framework. Employee relations. 2018; 40(2): 433-455.

45. KYEYUNE JN. Factors affecting staff turnover at ksmokateera and kagumire advocates in uganda (Doctoral dissertation, Uganda Management Institute). 2018.

46. Paul GD, Kee DMH. HR, Workplace Bullying, and Turnover Intention: The role of Work Engagement. Journal of Environmental Treatment Techniques. 2020; 8(1): 2327.

47. Afsar B, Shahjehan A, Shah SI. Frontline employees' high-performance work practices, trust in supervisor, jobembeddedness and turnover intentions in hospitality industry. International Journal of Contemporary Hospitality Management. 2018; 30(3): 1436-1452. 48. Nabi MN, Ahmed AAT, Rahman MS. The empirical study on human resource management practices with special reference to job satisfaction and employee turnover at Investment Corporation of Bangladesh. Human Resource Management Research. 2017; 7(1):54-64.

49. Pandita D, Ray S. Talent management and employee engagement-a meta-analysis of their impact on talent retention. Industrial and Commercial Training. 2018; 50(4): 185-199.

50. Valaitis R, Meagher-Stewart D, Martin-Misener R, Wong ST, MacDonald M, O'Mara L. Organizational factors influencing successful primary care and public health collaboration. BMC health services research. 2018; 18(1): 420 . 